Cosomys, a New Genus of Vole from the Pliocene of California

Author(s): Robert W. Wilson

Source: Journal of Mammalogy, Vol. 13, No. 2 (May, 1932), pp. 150-154

Published by: American Society of Mammalogists

Stable URL: https://www.jstor.org/stable/1374052

Accessed: 13-01-2020 23:54 UTC

JSTOR is a not-for-profit service that helps scholars, researchers, and students discover, use, and build upon a wide range of content in a trusted digital archive. We use information technology and tools to increase productivity and facilitate new forms of scholarship. For more information about JSTOR, please contact support@jstor.org.

Your use of the JSTOR archive indicates your acceptance of the Terms \& Conditions of Use, available at https://about.jstor.org/terms

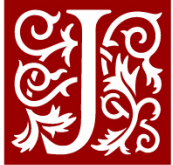

American Society of Mammalogists is collaborating with JSTOR to digitize, preserve and extend access to Journal of Mammalogy 


\title{
COSOMYS, A NEW GENUS OF VOLE FROM THE PLIOCENE OF CALIFORNIA
}

\author{
By Robert W. WiLson
}

[Plate 12]

Rodents are of rather common occurrence in the later Tertiary of North America, yet voles have been completely absent from the record with the exception of a single tooth of Neofiber found in the upper Pliocene San Pedro Valley beds of Arizona. ${ }^{1}$ Consequently material representing this important group should prove of interest in an interpretation of the history of the voles in North America.

The specimens described in this paper are from late Cenozoic mammal-bearing beds exposed on the flanks of the Coso Mountains along the eastern margin of Owens Valley, nine and one-half miles east of Olancha, California. The age of the deposits from which the rodent material comes has been tentatively regarded as upper Pliocene by Dr. Chester Stock of the California Institute of Technology. A determination of age has been afforded chiefly by horse material from the same locality.

The author wishes to thank Dr. Stock for the opportunity to study the material and for advice during the course of the investigation. Specimens of Recent voles were loaned for comparison by Mr. Donald R. Dickey of the California Institute of Technology, and by the United States National Museum. Preparation of the illustrations was supervised by Mr. John L. Ridgway.

Cosomys primus, gen. et sp. nov.

Holotype.-No. 500, Calif. Inst. Technology, Coll. Vert. Paleont.; a badly crushed skull with basicranial region and bullae missing, but with complete dentition. Left and right fragmentary rami; dentition complete in right ramus, left ramus with cheek-teeth broken out. From Calif. Inst. Tech. Vert. Pale. locality 131, nine and one-half miles east of Olancha, Inyo Co., California.

Paratypes.-Mandible, No. 501, with dentition complete in right ramus. Mandible, No. 502, with left $M_{1}$ and $M_{2}$.

Generic diagnosis.-Mandibular incisor passing from lingual to buccal side of tooth-row. Proximal end of mandibular incisor terminating slightly above dental foramen. Cheek-teeth developing roots in adult life. $M_{1}$ with three closed triangles following the posterior loop, and an anterior loop of complex pattern. Dentine spaces of teeth confluent. Enamel thick, usually not noticeably differentiated into thick and thin tracts. Upper incisors without grooves. Temporal ridges of interorbital region weakly fused.

${ }^{1}$ Gidley, J. W., U. S. Geol. Surv. Prof. Paper 131, p. 127, pl. 35, fig. 14, 1922. 
Specific diagnosis.-Teeth with littie or no cement. Inner triangles of lower teeth slightly larger than outer, especially on $\mathbf{M}_{3}$. Inner triangles of upper teeth with rounded apices. Third outer fold in $\mathrm{M}_{1}$ reduced to form a pit surrounded by enamel. Persistent "prism fold" ${ }^{2}$ on $\mathrm{M}_{1}$. Size approximately that of Mimomys pliocoenicus.

\section{SKULL AND DENTITION}

Study of the various genera of voles, living and extinct, shows that Cosomys resembles most closely in structure Arvicola and Mimomys. Neither of these genera is found in North America.

The skull of the genotype, Pl. 1, figs. 2, 2a, is too badly crushed to yield characters of importance, the region of the palate being almost entirely obliterated. The rostrum is not arched and the inferior border is straight from the palate to the anterior portion of the incisive foramina. The absence of an arched rostrum may be a primitive character for the straightness of the palate in this region is shown to some degree in Phenacomys and Clethrionomys, both primitive members of the existing voles. The temporal ridges in the interorbital region are only feebly fused in Cosomys. In this character the Californian genus appears to be intermediate between Mimomys, in which the temporal crests are not fused, and Arvicola in which the crests are clearly united, as seen at least in later Quaternary representatives of the genus.

In its major features the enamel pattern of the teeth is very similar to that in Arvicola and especially to that in Mimomys. $\mathrm{M}^{1}, \mathrm{M}^{2}, \mathrm{M}_{2}$, and $\mathrm{M}_{3}$ possess the characteristic pattern seen in voles. $\mathrm{M}^{1}$ (Pl. 1, fig. 4) has an anterior loop and four more or less closed triangles. $\mathrm{M}^{2}$ has an anterior loop and three alternating triangles. $\mathrm{M}^{3}$ possesses anterior and posterior loops, two triangles and the suggestion of a third, very small, postero-external triangle. In the first and second upper molars of Arvicola, in contrast to the corresponding teeth of Cosomys, the postero-external triangle is distinctly oblique to the principal axis of the toothrow. Moreover, the postero-internal re-entrant angle in $\mathrm{M}^{3}$ of Cosomys is deeper than in any of the specimens of Mimomys whose figures are available for comparison. This re-entrant angle is very deep and there is apparently no tendency to isolate the tip of the fold as in Mimomys pliocoenicus.

The position of the root of the mandibular incisor is clearly marked in the ascending ramus. The shaft of the condyle is bent inward with the posterior portion broad. The groove between molars and ascending ramus is open posteriorly, not pocketed as in Arvicola.

In the cheek-teeth of voles $M_{1}$ possesses perhaps the most complex enamel pattern. This tooth in Cosomys (Pl. 1, fig. 5) presents a posterior loop, three alternating triangles, and a complex anterior loop. The anterior loop exhibits the primitive "prism fold" of Hinton, even in a fairly worn tooth. An enamel islet is also present as in Mimomys pliocoenicus and in other species of this genus in the European Pliocene. In Cosomys where the teeth are devoid of cement the islet is in reality a pit surrounded by enamel. The origin of the pit in the Californian genus by an isolation of the tip of the third external re-entrant angle does not

${ }^{2}$ Hinton, Martin A. C., Monograph of the Voles \& Lemmings (Microtinae) Living and Extinct, vol. 1, p. 111, London, 1926. 
appear to be so clearly indicated as in Mimomys. It seems possible, at least, that the pit may have originated from an isolated tip of the third inner angle. However, if the pit were formed in this way it appears probable that greater tendency toward reduction of the inner angle would be exhibited than is actually the case. In either instance the angle has a greater forward extension than the corresponding angle in Mimomys, bringing the anterior tip opposite, or slightly in front of, the posterior margin of the third outer fold. If the islet or pit represents an isolation of the tip of the third outer angle it gives a forward direction to the angle instead of a backward direction as in very young specimens of Arvicola and in Mimomys pliocoenicus.

The pit or islet is present in two specimens of the first lower molars available. In a third specimen, representing this molar, the pit is absent but the crown shows greater wear than in the teeth in which the pit is present. The pit evidently persists long after the roots have started to form. With the exception of the anterior loop the tooth as a whole compares favorably with Arvicola. It resembles even more closely that in Mimomys, the chief difference being in the relation of the isolated enamel pit to the third inner and outer folds.

$\mathrm{M}_{2}$ has a posterior loop and four closed triangles. $\mathrm{M}_{3}$ has both posterior and anterior loops, and two closed triangles. These teeth are very similar to the comparable molars in Mimomys and in Arvicola.

The cheek-teeth in Cosomys appear to be somewhat wider than those in Recent Arvicola. In $\mathrm{M}_{1}$ however the relative width of crown may not differ greatly from that in the latter genus. In view of the small number of specimens available the ratios of the posterior cheek-teeth may not represent average values.

\section{RELATIONSHIPS}

The position or orientation of the lower incisor within the mandibular ramus, as it passes from the lingual to the buccal side of the tooth-row in its backward course, is evidently a distinguishing feature in which the genus Cosomys is like a vole and differs from the lemmings. In modern voles with rooted cheek-teeth representing primitive members of the Microti the root of the lower incisor terminates well below the posterior dental foramen. Although the cheek-teeth may be rooted in Cosomys the termination of the mandibular incisor in this genus at a point slightly above the dental foramen suggests that the latter type is not closely related to living voles but is an early representative of a more progressive stem. The relatively complicated enamel pattern of the anterior lobe of $M_{1}$ is believed by M.A.C. Hinton to be a primitive character.

Among living voles the genus Arvicola apparently resembles Cosomys more closely in structure than does any North American form. Viewing the history of development of the voles as at present known one may presume that the most important change in the dentition since the upper Pliocene has been an increase in the length of the crowns of the cheek-teeth, while only minor changes in crown pattern have occurred.

A single tooth, possibly $\mathrm{M}^{2}$, from the San Pedro Valley beds of Arizona, was referred to Neofiber by Gidley. ${ }^{3}$ The base of the crown in this specimen is closed and small roots are present, in which respect this type differs from living speci-

${ }^{3}$ Gidley, J. W., op, cit., p. 127, 1922. 
mens of the genus. Possibly Gidley's specimen belongs to the genus Cosomys . Unfortunately the description and illustrations do not permit a more detailed comparison with the Californian material. It is of interest to note that the San Pedro Valley beds, whence this specimen came, are also regarded as of upper Pliocene age. According to Gidley the collections obtained from these deposits are known principally from two localities. While the latter are inseparable in so far as their stratigraphic position is concerned the two assemblages suggest a difference in age. The locality that yielded the tooth of Neofiber furnished also the remains of Dibelodon, Equus, Lama, Procamelus, Pliauchenia, Odocoileus, Merycodus, and Glyptotherium. The list includes both Pliocene and Pleistocene genera. A reworking of the material in the course of deposition of the sediments at this locality may account for the apparently anomalous association of types. Were this ultimately determined to be the case $N$ eofiber may be a contemporary of Equus, Lama, and Odocoileus, and of Pleistocene age.

The nearest relatives of Cosomys among fossil forms, as suggested by structural characters on which comparison can be made at present, are the genera Mimomys and Arvicola of the European Pliocene and Pleistocene. According to Hinton ${ }^{4}$ the genus Mimomys ranges upward stratigraphically from the Norwich Crag to the High Terrace of the Thames while the earliest occurrence of Arvicola is recorded from the Middle Terrace of the Thames. The latter genus survives today and is presumed to have been derived from Mimomys.

While the Norwich Crag is regarded by most European authorities as of upper Pliocene age, Haug refers this formation to the lower Pleistocene. In either instance, however, the Norwich Crag fauna has a position in the later Cenozoic succession near that of the assemblage from the deposits in the region of the Coso Mountains.

The geographic separation of the Californian and European localities lessens somewhat the possibility of generic identity of Cosomys and Mimomys, although it should be borne in mind that some living genera of rodents are widespread in their distribution over the northern hemisphere. Possibly the Californian genus is older geologically than Mimomys. Aside from the geographic and geologic position of these forms it is possible that the characters in which Cosomys resembles Mimomys relate to the more primitive structural features which may be found in other Pliocene voles. There are, on the other hand, some noteworthy differences. In Cosomys the temporal ridges are weakly fused, while in the European genus this fusion is not known to occur. In the late Pleistocene and Recent Arvicola, however, the crests are fused so far as is known. Moreover, the enamel patterns developed in the last upper molar and first lower molar of Cosomys differ at least to a slight extent from those seen in Mimomys. For the purposes of comparison it should be stated that the alveolar length of the lower tooth row of Mimomys varies from 7.0 to $8.5 \mathrm{~mm}$., while that of Cosomys varies from 7.1 to $7.8 \mathrm{~mm}$.

${ }^{4}$ Hinton, Martin A. C., op. cit., vol. 1, pp. 126-136, London, 1926. 
Comparative measurements (in millimeters)

\begin{tabular}{|c|c|c|c|c|c|}
\hline & 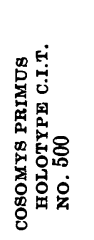 & 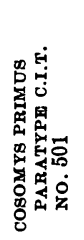 & 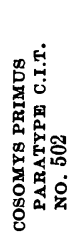 & 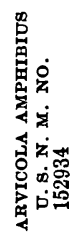 & 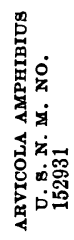 \\
\hline $\begin{array}{l}\text { Least width of interorbital constric- } \\
\quad \text { tion } \ldots \ldots \ldots \ldots \ldots \ldots \ldots \ldots \ldots\end{array}$ & 3.5 & & & 4.3 & 5.0 \\
\hline Length of nasal. ................ & $9.5^{\mathrm{a}}$ & . & $\ldots$ & 10.9 & 10.7 \\
\hline Width of nasal. . . . . . . . . . . & $2.9 ?$ & 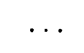 & 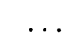 & 4.4 & 4.9 \\
\hline $\begin{array}{l}\text { Length of diastema between } \mathrm{I} \text { and } \\
\qquad \mathrm{M}^{1} \ldots \ldots \ldots \ldots \ldots \ldots \ldots \ldots \ldots \ldots\end{array}$ & 9.6 & $\cdots$ & . & 15.6 & 14.2 \\
\hline $\begin{array}{l}\text { Height from edge of palate to top of } \\
\text { skull } \ldots \ldots \ldots \ldots \ldots \ldots \ldots \ldots\end{array}$ & 8.6 & & & 14.0 & 13.0 \\
\hline $\mathrm{M}^{1}$, anteroposterior diameter ....... & 2.7 & $\ldots$ & $\cdots$ & 3.9 & 3.6 \\
\hline $\mathrm{M}^{1}$, transverse diameter. ......... & 1.7 & $\ldots$ & . & 2.2 & 2.1 \\
\hline $\mathbf{M}^{2}$, anteroposterior diameter ...... & 2.1 & . & . & 2.7 & 2.7 \\
\hline $\mathbf{M}^{2}$, transverse diameter $\ldots \ldots \ldots \ldots$ & 1.6 & $\ldots$ & .. & 1.8 & 1.8 \\
\hline $\mathrm{M}^{3}$, anteroposterior diameter ....... & 2.1 & $\ldots$ & . & 2.7 & 2.6 \\
\hline $\begin{array}{l}\mathrm{M}^{3} \text {, transverse diameter........... } \\
\text { Length of upper tooth row (alveo- }\end{array}$ & 1.3 & $\ldots$ & & 1.5 & 1.5 \\
\hline lar $) \ldots \ldots \ldots \ldots \ldots \ldots \ldots \ldots$ & $7.4^{\mathrm{a}}$ & & . & 10.3 & 9.4 \\
\hline $\mathbf{M}_{1}$, anteroposterior diameter...... & 3.2 & 3.2 & 3.0 & 4.2 & 3.8 \\
\hline $\mathbf{M}_{1}$, transverse diameter $\ldots \ldots \ldots$ & 1.5 & 1.6 & 1.4 & 1.9 & 1.9 \\
\hline $\mathbf{M}_{2}$, anteroposterio-diameter. ..... & 2.0 & 2.2 & 1.8 & 2.5 & 2.6 \\
\hline $\mathbf{M}_{2}$, transverse diameter.......... & $1.5 ?$ & 1.5 & 1.3 & 1.5 & 1.7 \\
\hline $\mathrm{M}_{3}$, anteroposterior diameter ....... & 1.9 & 1.8 & $\ldots$ & 2.5 & 2.7 \\
\hline $\begin{array}{l}\mathrm{M}_{3} \text {, transverse diameter........... } \\
\text { Length of lower tooth row (alveo- }\end{array}$ & 1.1 & 1.3 & . & 1.2 & 1.3 \\
\hline lar $) \ldots \ldots \ldots \ldots \ldots \ldots \ldots \ldots$ & 7.1 & 7.8 & 7.6 & 9.9 & 9.5 \\
\hline
\end{tabular}

- Approximate.

Balch Graduate School of the Geological Sciences, California Institute of Technology. 


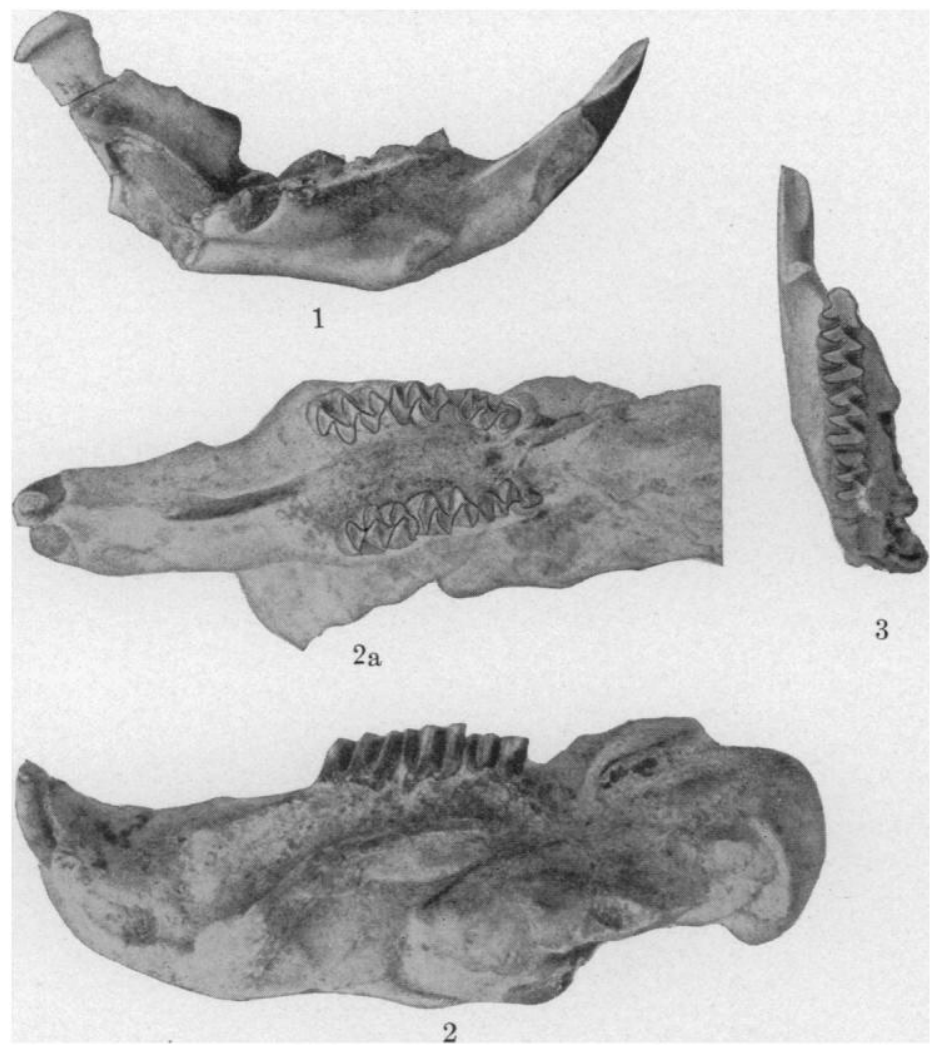

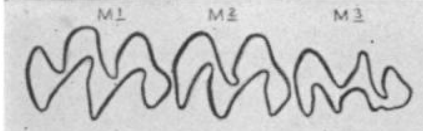

4

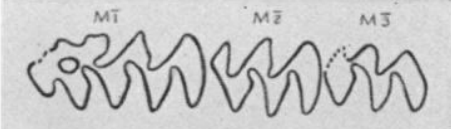

5

Skull, Mandibles, and Cheex Teeth of Cosomys primus Wilson

Fig. 1. Cosomys primus Wilson; lateral view of ramus; cat. no. 500, Calif. Inst. Technology, Coll. Vert. Paleont.; Upper Pliocene, Coso Mountains, Calif.; approx. X 3.

Figs. 2, 2a. Cosomys primus Wilson; lateral and ventral views of skull; cat. no. 500, Calif. Inst. Technology, Coll. Vert. Paleont.; Upper Pliocene, Coso Mountains, Calif.; approx. X 3.

Fig. 3. Cosomys primus Wilson; dorsal view of ramus; cat. no. 501, Calif. Inst. Technology, Coll. Vert. Paleont.; Upper Pliocene, Coso Mountains, Calif.; approx. X 3.

Fig. 4. Cosomys primus Wilson; right upper cheek teeth; cat. no. 500, Calif. Inst. Technology, Coll. Vert. Paleont.; Upper Pliocene, Coso Mountains, Calif. approx. X 5.

Fia. 5. Cosomys primus Wilson; right lower cheek teeth; cat. no. 500, Calif., Inst. Technology, Coll. Vert. Paleont.; Upper Pliocene, Coso Mountains, Calif.; approx. X 5. 